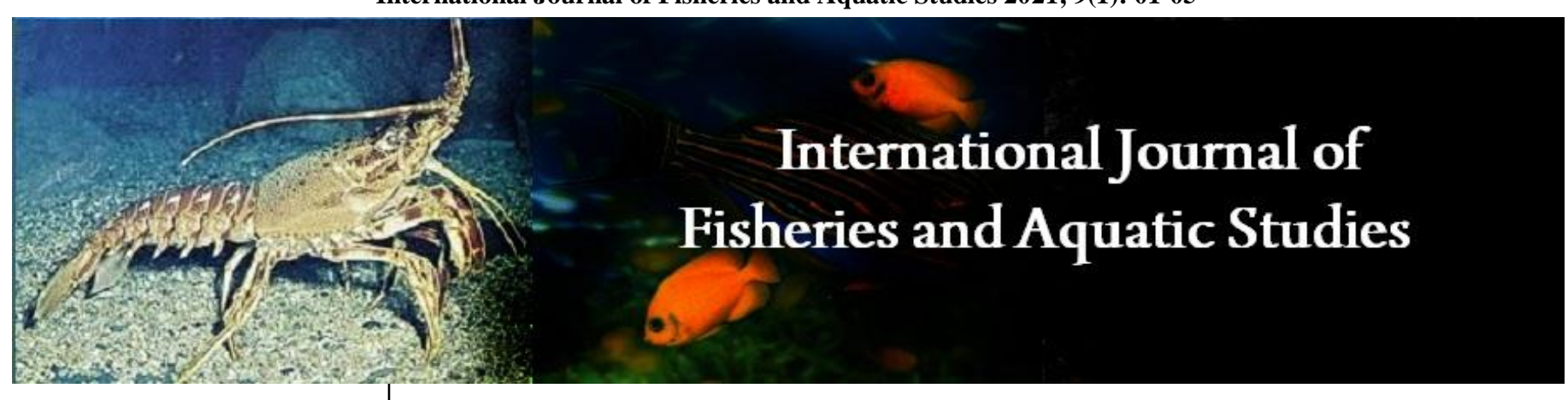

E-ISSN: 2347-5129

P-ISSN: 2394-0506

(ICV-Poland) Impact Value: 5.62

(GIF) Impact Factor: 0.549

IJFAS 2021; 9(1): 01-05

(C) 2021 IJFAS

www.fisheriesjournal.com

Received: 22-10-2020

Accepted: 02-12-2020

Alemayehu Abebe Wake

Batu Fish and Other Aquatic

Life Research Center, Batu,

Ethiopia
Corresponding Author: Alemayehu Abebe Wake Batu Fish and Other Aquatic Life Research Center, Batu, Ethiopia

\section{Opportunities and its challenges in fish production: The case of Lake Koka, East Showa Zone, Oromia National Regional State, Ethiopia}

\author{
Alemayehu Abebe Wake
}

DOI: https://doi.org/10.22271/fish.2021.v9.i1a.2381

\begin{abstract}
The study was conducted to assess opportunities and challenges in fishery the case of Lake Koka, Ethiopia. Interview, focus group discussion and personal observations were used as means of data collection. Response was solicited from households within the catchment area of the reservoir, key informants, fish cooperative chairman and cooperative member households. The collected data were analyzed through descriptive statistics and narration. At the study area fishing activities were done through cooperative form that make an opportunity to operate fishing at full time. In the study area farmers were used fishing mainly as direct income generation that used for direct use of family members. Fishing activities were also dominated by male household having of fishing experience of below five (5) years. In addition to fishing, those household support their livelihoods with other agricultural activities. Increasing the demand of fish, availability of commercially consumed fish species and Good market outlet are some of the main opportunity that was specified by fishing households. Evasive weed water hyacinth, inadequate government support and water pollution are mentioned as the main challenge with insufficient value chain and unreliable market situation. So, it should be need an emphasis on integrated management to overcome challenges for effective utilization fish resources.
\end{abstract}

Keywords: Challenges, Lake Koka, fish, opportunities

\section{Introduction}

Fishing is one of the oldest economic occupations of mankind and is carried out for subsistence and commercial purposes. From earliest time, fishing has been a major source of food for human and a provider of employment and economic benefits to growing world's population ${ }^{[6,5]}$. Fisheries refer to an organized effort by humans to catch fish or other aquatic ${ }^{[6,7]}$. Fisheries are good source of income, food and job creation ${ }^{[4]}$. The sector primarily used as source of food and income for many people around the world ${ }^{[1] .}$ In Ethiopia, fish production and the majority of fish protein supply is available around Lake Tana and the grater Rift Valley Lake ${ }^{[12]}$. The fish consumption status has grown gradually in developing regions. However, it is still considerably lower than that in more developed regions ${ }^{[5]}$.

In Ethiopia, fishing production is takes place on different lakes, rivers, streams, reservoirs and substantial wetlands. Those diverse water bodies have a great importance in socio-economic, ecological and scientific purpose ${ }^{[8]}$. According to Tesfaye and Walff ${ }^{[12]}$, the country have an opportunity to produce a potential of 94,500 tone of fish per year. But, currently the country produce below its potential due to different challenges. Even, from year to year the production is show the rapid reduction of the production including on the main fishery potential area. Due to that, the role of fishery is insignificant on the economy of country ${ }^{[8]}$.

The current production is still far below the estimated potential yield, which suggests the possibility for further expansion of the fishery. Ethiopia is endowed with several water bodies that contain a high diversity of aquatic fauna. Reservoir fishery plays an important role in the economy of the country and the livelihoods of the people living adjacent to those reservoirs. Fisheries resource in Ethiopia, in spite of its significant contribution to poverty alleviation and food security, is an unexploited natural resource ${ }^{[10]}$. Ethiopia has many lakes and reservoirs of which Lake Koka is located in Lume District. The Lake is fitting for fishery and aquaculture development to supply fish for the community. However, there is a lack of information on opportunities and its challenges for proper utilization of the resource for sustainable utilization 
and development of the fish sector in the area. Therefore, this study sets to assess opportunities and its challenges for fish production of Lake Koka.

\section{Materials and Methods}

The study was conducted in Koka Lake which is located in the boundary of between East Shoa Zone (between Lume and Bora district), and Arsi Zone (bordered with Dodota district). It is situated at around 90 kilometers southeast of Addis Ababa. At Lume district Koka Lake is one of the main lake that used for different economic and ecological purposes. In the district there are two rivers namely Awash and Mojo that flow toward to Koka Lake as Inlet Rivers. The Lake has a surface area of about $255 \mathrm{~km}^{2}$ with a maximum depth of 14 $\mathrm{m}$. The mean depth of the lake is around $9 \mathrm{~m}$ with shore line of $195-205 \mathrm{~km}$ distance.

It is located between $8^{0} 2^{\prime}$ to $8^{0} 26^{\prime} \mathrm{N}$ latitude, $39^{0}$ to $39^{0} 10^{\prime} \mathrm{E}$ longitude and an altitude elevation of 1660 meters above sea level. Awash and Mojo Rivers are the inflowing rivers to the Lake. Its water in- and outflow is mainly provided by the Awash River. The lake is serving for different purposes, such as hydroelectric power generation and from small to large irrigation. The lake is also important for fishing activities [1] that mainly used people living in the vicinity of the lake.

This study was used the cross-sectional research design that focus on both qualitative and quantitative nature of data. The study employed simple random selection procedures to identify the sample households who are using fish as the sources of livelihood. The primary data were collected using structured questionnaire interview, focus group discussion and field observations. The total of 172 respondents were participated in the study for primary data generation who were randomly selected from fishing households. During the field survey period it was observed that Lake Koka was a restricted area and fishing were permitted for legalized fishery cooperative members only. The community did not have an access to fish unless illegally.

As Key Informant Interviews (KIIs) one fishery cooperative leaders, two local level officials and two fishery experts who lived and served with the locality were used for additional data generation. Focus group discussion (FGD) also held that helps to generate data on group dynamics, and allows a small group of respondents to guide by moderator, to focus on key issue of the research objective. The data were analyzed by combining quantitative and qualitative methods. Descriptive statistics was used to summarize and analyze the quantitative data obtained by questionnaires using SPSS V.20.

\section{Results and Discussions}

\subsection{Socio-economic characteristics}

The households surveyed along Lake Koka Darar Denbela, Dungugi Bekele and Koka Nagawo Kebeles from Lume Districts. Under this three Kebeles all fishing households were work by organizing fishery cooperative that allow for fully operate fishing activities. On those specific research site, fishing is considered as a regular component of their livelihood strategy which was done every season in year. The data confirm that fishing is the best family business involving the male head of the household, his wife and their children. There was only three legally registered fishery cooperative on side of Lume district.

From household survey, the majority $(92.44 \%)$ of the fishery cooperative members were men. The mean age of the sample household's heads was 32.8 years with maximum and minimum age of 56 and 18 years respectively. The educational back ground of the cooperative members indicated all of them had attended primary school education with the mean of 2.58 year of schooling. The mean household size was collected continuously and calculated with adult equivalent ration. Based on Table 1 the mean household size were 3.7 with the maximum and minimum of 10.8 and 1 persons respectively. From the total responds, $82.56 \%$ were married and only $17.44 \%$ of households were unmarried.

Table 1: Socioeconomic characteristics of fishing households

\begin{tabular}{|c|c|c|c|c|}
\hline Variables & Mean & SD & Min & Max \\
\hline Age & 32.18 & 7.56 & 19 & 58 \\
\hline Family size & 3.7 & 2.1 & 1 & 10.8 \\
\hline Educational level & 2.58 & 2.36 & 0 & 10 \\
\hline Land size & 1.2 & 0.54 & 0 & 3.75 \\
\hline Livestock holding & 3.7 & 2.5 & 0 & 7.32 \\
\hline
\end{tabular}

Land holding is considered to be a key fixed and the major productive asset in agrarian countries including Ethiopia. The mean of land size for fishing households were 1.2 hector of land respectively with corresponding maximum of 3.75 hectors of land. To assess the livestock holding of each household, the Tropical Livestock Unit (TLU) was calculated the sampled household holds raged from 0.00 to 7.32 TLU for fishing households. The mean livestock holding for fishing households were about 3.7 in TLU.

As data indicated in Table 2, fishing households were had an experience that ranged from 2 up to 40 years with the average of 9.57 years. The majority of the respondent $(58.14 \%)$ had fishing experience from 3 to 10 years, while $17.44 \%$ had a fishing experience of 10 to 15 years and $24.42 \%$ of fishing households were had a fishing experience of 15 to 40 years. This is good year of experience in fishing helps to improve fishing activities from harvesting to marketing that help to increase farm household income from the sector.

Table 2: Marital status, fishing experience and fish consumption status

\begin{tabular}{|c|c|c|c|}
\hline Category & Indicator & Frequency & Percent \\
\hline \multirow{2}{*}{ Sex } & Male & $\mathbf{1 5 9}$ & $\mathbf{9 2 . 4 4}$ \\
\cline { 2 - 4 } & Female & $\mathbf{1 3}$ & $\mathbf{7 . 5 6}$ \\
\hline \multirow{2}{*}{$\begin{array}{c}\text { Marital status of } \\
\text { household }\end{array}$} & Married & 142 & 82.56 \\
\cline { 2 - 4 } & Unmarried & 30 & 17.44 \\
\hline \multirow{3}{*}{$\begin{array}{c}\text { Fishing experience } \\
\text { (in year) }\end{array}$} & $3-5$ & 51 & 29.65 \\
\cline { 2 - 4 } & $5-10$ & 49 & 28.49 \\
\cline { 2 - 4 } & $10-15$ & 30 & 17.44 \\
\cline { 2 - 4 } & $15-40$ & 42 & 24.42 \\
\hline \multirow{2}{*}{$\begin{array}{c}\text { Fish consumption } \\
\text { status }\end{array}$} & Regularly & 163 & 94.77 \\
\cline { 2 - 4 } & Occasionally & 9 & 5.23 \\
\hline
\end{tabular}

Consumption of fish is one of the most important in health that attributed to the omega-3 long-chain polyunsaturated fatty acids present in fish. Protein profile of fish contains up to 22 of the essential amino acids in a well-balanced ration ${ }^{[7]}$, low cholesterol level compared to red meat and is easily digestible due to its high soft tissue. As its high nutritional value, fish is highly recommended as a dietary component for both the young and old person. From the total fishing household $94.77 \%$ were consume fish regularly and the remaining $5.23 \%$ of sampled responds were consume occasionally (Table 2).

\section{Opportunities and Challenges in fishing activities 4.1 Opportunities for fishing in the study area} Increase demand: In the study area farmers were used fishing mainly as immediate income generation that used for many purpose in household. All fishing households (100\%) 
mentioned that, fishing demand is increasing from time to time in the market. Based on male age of 37 focus group discussant from fishing household Mr. Gudeta Galata respond on the demand of fish from time to time that shows an increment in the market. From personal observation, the fishing household, mainly completed the whole production at landing site on their boat, especial on feasting days. The literature also confirmed that, the projected fish demand is rising from 67,000 tonne in 2003 to 118,000 tonne at $2025^{\text {[9] }}$.
Availability of commercially consumed fish species: Based on collected data from the main fishing source Lake Koka, the respondents mentioned that three commercially important fish species which used as income generation in the market. In the study area Nile tilapia (Oreochromis niloticus) (Figure 1a), Common carp (Cyprinus carpio) (Figure 1b) and Catfish (Clarias gariepinus) (Figure 1c) were the main targeted and leading species in overall production. Those fish species had more demand on consumer and any level of fish market.

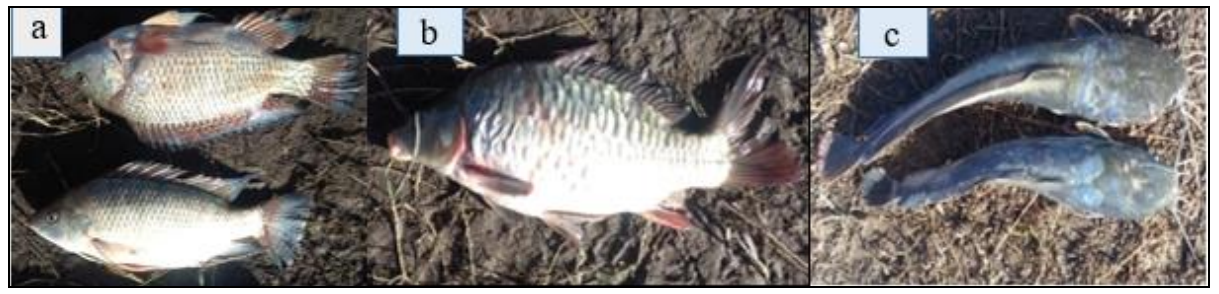

Fig 1: Targeted fish species at Lake Koka

These three species successfully colonize the Lake and are able to form different size classes indicating the species are well adapted the Lake environment. This is consistent with the finding of Tesfaye and Wolff, ${ }^{[12]}$ indicate to that in fishing Oreochromis niloticus, Clarias gariepinus and Cyprinus carpio are the most principal fish species in Lake Koka. In line with this fact almost all fishing households $(99.42 \%)$ were confirm that, availability of commercially consumed fish species as main opportunities for fishing in the study area. Based on male age of 46 focus group discussant from fishing household Mr. Koricho Debele indicated that, all mostly harvested fish species has good demand by consumer and market.

Good market outlet: From geographical location Lume district found at center for many big city or town in the country. Comparatively, the district have good access to road and for fish marketing. From survey result, about $97.09 \%$ respondents were specified that, Lume district has good market outlet for improving fish marketing. As female age of 32 key informant development agent from Koka Negawo Kebele Mrs. Chaltu Abomssa revealed that, "Lume district fishing households were had good market outlet for selling all harvested fish species from Lake Koka'. But, she mentioned that due to lack of well-established fish value chain farmers is not well benefited from this main opportunity as expected.

Free access to water bodies: In addition to Lume district, Koka Lake is border with Bora, Adama and Dodota districts. For those district availability of such Lake serves and support different household in different aspect from fishing to watering for livestock and home consumption. From fishing households about $95.35 \%$ farmers were told availability of Lake Koka as good opportunity for the development of fishery. Based on female age of 36 focus group discussant from fishing household Mrs. Mestawet Melaku confirmed that, availability of Lake Koka is one of the key asset for Lume district. She stress that, due to this water bodies many rural farmers well benefited through fishing and irrigation farm which is an opportunity for all farmers.

Small initial capital: In the study area farmers were participant in different livelihood activities to ensure family need. As the compare with other farm activities about $70.93 \%$ fishing household specified as fishing need small initial capital for new beginners. According to As male age of 32 development agent from Dhungugi Kebele Mr. Rorisa Kafani mentioned that, different individuals and organizational bodies have been conducting different assessment on the lake which is help to understand the recent information related to fishing activities on the existing situation of the Lake can be found. They also confirmed that if fishing activities are performed in sustainable manner, it will be an opportunity to support the livelihood of rural communities especially for people residing nearby the water body.

Table 3: Opportunity for fishing in the study area (multiple responses)

\begin{tabular}{|c|c|c|c|}
\hline Opportunities & Frequency & Percent & Rank \\
\hline Small initial capital & 122 & 70.93 & 5 \\
\hline Free access to water bodies & 164 & 95.35 & 4 \\
\hline Increase demand & 172 & 100.00 & 1 \\
\hline $\begin{array}{c}\text { Availability of commercially } \\
\text { consumed fish species }\end{array}$ & 171 & 99.42 & 2 \\
\hline Good market out let & 167 & 97.09 & 3 \\
\hline
\end{tabular}

\section{Challenges in fishing activities}

Expansion of water hyacinth: For all fishing households, fishing is the only main income source for their livelihood; however, the sustainability of the resource for long period of time is in question. The most serious problem mentioned by fishing household in Lake Koka is the expansion of invasive water weed called water hyacinth (Figure 2). All fishing households were blaming water hyacinth as one of the main challenge for fishing activities. The weed has infested water bodies in Lume district in east Showa zone of Oromia Region and with connection to the Awash River and Koka Lake.

This invasive weed can destroy the fishing material and make fishing activities more tiring. From the total fishing households the majority of fishermen have lost their fishing equipment's during fishing season of last year because of the water hyacinth. As female age of 29 focus group discussant from fishing household Mrs. Gadise Gamada told that, the weed also reduce the amount of fish caught per unit effort. As male age of 32 development agent from Dhungugi Kebele Mr. Rorisa Kafani mentioned that, the expansion of water hyacinth weed also affect the irrigation activities in addition to fishing. As data from district Agricultural office indicates that, currently more than 2000 ha of land were covered by this invasive weed in Lume district. 
This finding is similar with to Asmare et al. ${ }^{[2]}$ who reported that the expansion of water hyacinth negatively affect fishers in Lake Tana by increasing costs of fishing and reducing the amount of fish caught. Other study also confirm that the weed
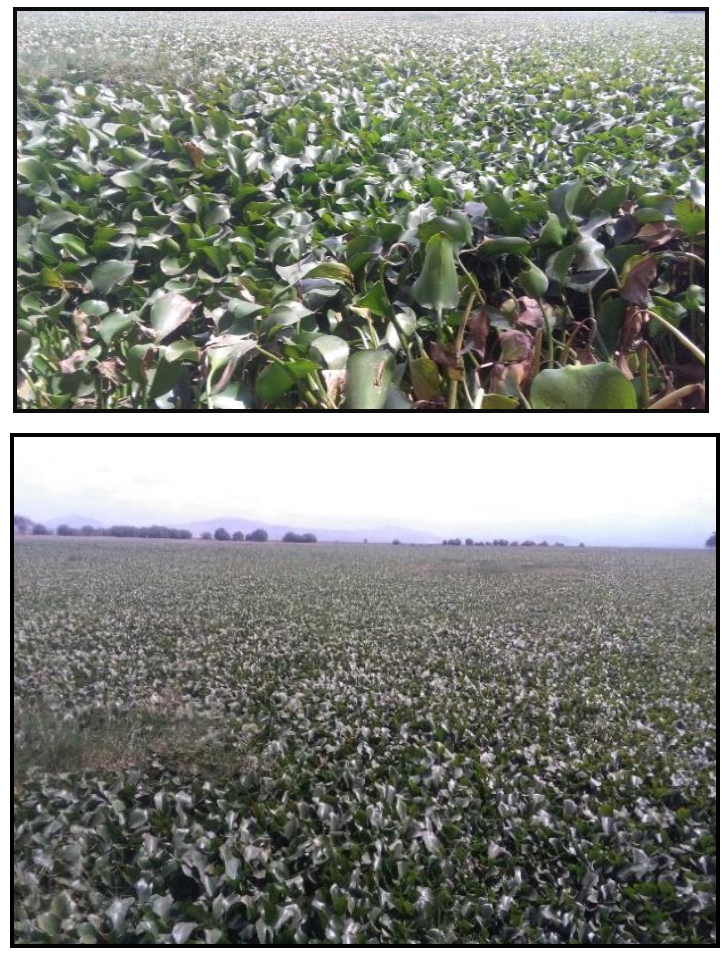

Fig 2: Expansion of water hyacinth in Lume district at Koka Lake, February, 2020

Absence of adequate government support, poor policy and regulatory framework: Absence of adequate government support to the development of fishery sector is the second critical problem mentioned by $98.26 \%$ of the respondents (Table 3). As male age of 48 focus group discussant from fishing household Mr. Gamahu Debela confirm that, the government was weak in delivering training and material provision with all necessary follow-up. Similarly, from survey, the respondents also mentioned that poor policy and regulatory framework $(65.12 \%)$ are the other challenges for fishing households. The presence of fishery proclamation which contributes control illegal fishing instruments, protect fisheries from over fishing and maintain the overall fishing environment did not safeguard the sector. About 59.30 percent of the farmers also responded that they were facing problems of lack of basic infrastructure and fishing equipment's.

Water pollution: Due to its proximity to the capital city as well as some other industrial towns, Koka Lake and its aquatic ecosystem has been under increasing anthropogenic pressure. The other major challenging factors are pollution coming from different factories and the surrounding large irrigation farms. This problem was noted by $78.5 \%$ of the respondents (Table 4). According to the respondents mentioned that chemicals that affect water quality of the Lake as well as the Lakes ecosystem are mainly released from different factories based in the district especially around Mojo Town trough Mojo River.

Chemical pollutants released from Ethiopia Tannery PLC affect the lake biodiversity specifically the fish resource according to the fishing household's respondents from Dhungugi Bekele Kebele. Due to this pollution they observed is considered as a constraint to the development of the country which has a negative impact on electricity generation, aquatic ecosystems, agriculture, transportation, living conditions and social structures in addition to fishing ${ }^{[3]}$.

unhealthy and dead fish on the border of lake during fishing time. As the respondents told during the fish collection process, the harvested fish start to spoil in net before reach to the landing site. I also observed that Ethiopian Tannery Factory discharging polluted liquid in milky white color with very pungent odor through waste disposal canal to Lake Koka (Figure 3).

This study finding is in line with FAO ${ }^{[5]}$ report that the sewage from factories is the sources of major pollutants affecting water bodies and their fisheries. The same report mentioned that the extraction of minerals from Lake Abijata, tannery at Koka Reservoir and the textile industries at Awassa and Arba Minch can affect the fisheries status. As male age of 28 development agent from Darar Danbela Kebele Mr. Hussen Kemal mentioned that, farm activities that done at the shore of lake also other source of Lake Water pollution. The study conducted by Mitike ${ }^{[9]}$ also reported, the farm activities had polluted Lake Ziway in addition to sewage that release from factories.
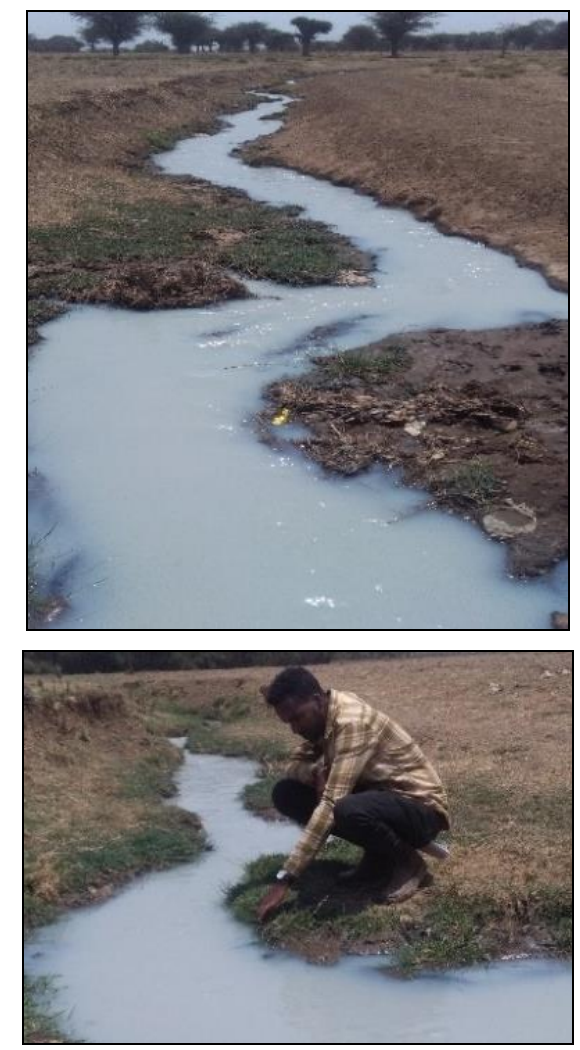

Fig 3: Waste disposal canal to Lake Koka from Ethiopian tannery, February, 15/2020

Lack of basic infrastructure and fishing equipment's: Lack of basic infrastructure and fishing equipment's were also mentioned as main problems by $59.30 \%$ of the respondents while about $67.44 \%$ of respondent fishing households stated insufficient value chain and lack of reliable market as challenges for fishing activities. From my personal observation fishers had no any stable place and storage facility to preserve harvested fish until marketing. From personal observation, fishermen were prepared fish fillet near the lake shore, a site which is not clean enough and may cause unhygienic problems. Due to lack of storage and transporting 
facilities fishing households were selling their products at low prices during the periods of high production. In addition to this, marketing price of fish was seasonal that fluctuated based on market demands.

Lack of improved technologies and thefts: Existence of lack of improved technologies and thefts problems were responded positively by 55.81 and 28.49 percent of fishing households, respectively (Table 4). According to all focus group discussants from fishing households respond that, the lake is mainly exploited through illegal fishing materials due to poor lake management and controlling mechanism. This lead to the expansion of illegal fishing and theft problems in different landing site. The problem is high during off-farm and fasting season.

From group discussion I understand that fishing activities were performed throughout the year with improper fishing methods. Continues fishing without lake management will later bring overfishing for mostly targeted fish species. Even if catching under-sized fish is not legally allowed, the fishing households were observed using the illegal small-sized mesh to collect the under-sized fish to compete for the open access resource. From my personal observation, the majority of fishing households were used $6 \mathrm{~cm}$ stretched mesh size for gillnets which is different from fishery co-management approach was developed in 2013 for most lakes and reservoirs mesh size limitation of $10 \mathrm{~cm}$. Due to that at landing site the amount of catch of available fish species in the catch composition was very small. This activity directly leads to overexploitation of the resource that affects resource sustainability.

Table 4: The major challenges in fishing activities (multiple response)

\begin{tabular}{|c|c|c|c|}
\hline Challenges & Frequency & Percent & Rank \\
\hline Water hyacinth & 172 & 100.00 & 1 \\
\hline Lack of basic infrastructure and fishing equipment's & 102 & 59.30 & 6 \\
\hline Lack of improved technology & 96 & 55.81 & 7 \\
\hline Insufficient value chain and reliable market & 116 & 67.44 & 4 \\
\hline Poor policy and regulatory frame work for fishing & 112 & 65.12 & 5 \\
\hline Inadequate government support & 169 & 98.26 & 2 \\
\hline Water pollution & 135 & 78.5 & 3 \\
\hline Theft & 49 & 28.49 & 8 \\
\hline
\end{tabular}

\section{Conclusions and Recommendations}

In Lume District Lake Koka is one of the main and the only source of fishing place. Small initial capital, free access to water bodies, increase demand, availability of commercially consumed fish species and good market out let were the main opportunity in the study area. Fishing in the reservoir was conducted by legally registered fishermen cooperative each other day, though illegal fishing takes place. There were several challenges for fishing including water hyacinth, inadequate government support, water pollution, insufficient value chain and reliable market, poor policy and regulatory frame work for fishing, lack of basic infrastructure and fishing equipment's and lack of improved technology.

So, Lume district development and fishery office should work with all concerned bodies to provide day to day follow up with adequate technical and financial support to create reliable market situation and to solve or at least to mitigate those challenges. Specifically, the status of lake pollution, source and the extent of each waste disposal should clearly studied and correction must be taken to overcome those problem.

\section{References}

1. Ann G, Sewmehon D, Melaka T. Marketing systems for fish from Lake Tana, Ethiopia: Opportunities for marketing and livelihoods; Annual Report 2007, 5.

2. Asmare E, Demissie S, Tewabe D, Endalew M. Impact of climate change and anthropogenic activities on livelihood of fishing community around Lake Tana, Ethiopia. EC Agriculture 2017; 3(1):548-557.

3. Bhattacharya A, Haldar S, Chatterjee P. Geographical distribution and physiology of water hyacinth (Eichhorni acrassipses) the invasive hygrophyte and a biomass. International Journal of Chemical Technology Research 2015;7(4):1849-1861.

4. Bilame, O. Contribution of Lake Victoria small-scale fisheries to poverty alleviation. A Case Study of Tanzania Small-scale Fisheries. Agricultural Science and Technology 2012;2:1268-1278.

5. FAO. The State of World Fisheries and Aquaculture Contributing to food security and nutrition for all. Rome 2016, 200p. www.fao.org/3/a-i5798e.pd

6. FAO. The State of World Fisheries and Aquaculture Report 2004. www.fao.org/docrep/007/y5600e/y5600e04.htm

7. FAO. The State of World Fisheries and Aquaculture. Opportunities and challenges. Rome 2014. www.fao.org/3/a-i5555e.pdf.

8. Janko A. Assessment of fish products demand in some water bodies of Oromia, Ethiopia. International Journal of Agricultural Science 2013;3(8):628-632.

9. Janko A. Fish Production, Consumption and Management in Ethiopia. International Journal of Economics and Management 2014;3:183.

10. Kebede A, Meko T, Hussein A, Tamiru Y. Review on Opportunities and Constraints of Fishery in Ethiopia. International Journal Poultry Fish Science. 2017;1(1):1-8.

11. Mitike A. Fishermen's willingness to pay for fisheries management: the case of lake Ziway, Ethiopia. MSc. thesis Submitted to the School of Agricultural Economics and Agribusiness. Haramaya University 2015, Pp33.

12. Tesfaye G, Wolff M. The state of inland fisheries in Ethiopia: a synopsis with updated estimates of potential yield. Ecohydrology and Hydrobiology 2014;14:200-219. 